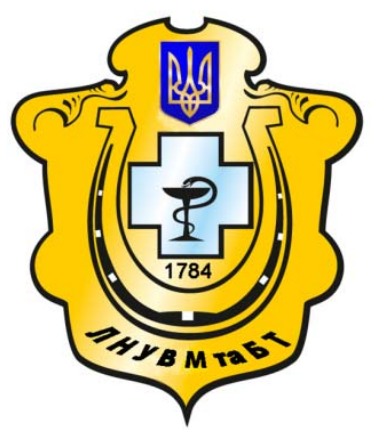

Науковий вісник Львівського національного університету ветеринарної медицини та біотехнологій імені С.3. Гжицького

Scientific Messenger of Lviv National University of Veterinary Medicine and Biotechnologies named after S.Z. Gzhytskyj

doi:10.15421/nvlvet7146

ISSN 2413-5550 print

ISSN 2518-1327 online

$\underline{\text { http://nvlvet.com.ua/ }}$

УДК 619: 616.9 : 621.385 .6

\title{
Властивості Salmonella typhi за дії електромагнітного випромінювання надвисокої частоти
}

\author{
О.В. Яблонська, Н.Я. Мех, Т.А. Духнич \\ yablonska.oksana@gmail.com \\ Національний університет біоресурсів і природокористування Украӥни, \\ вул. Героїв Оборони, 11, м. Київ, 03041, Україна
}

В Украйні роль сальмонел в етіології кишкових захворювань людей і тварин залишається важливою, оскільки спостерігаються зміни у сероваріантній структурі ичи патогенів, які уміло адаптуються до умов довкілля. Без вивчення біологічних властивостей збудників, їх обліку неможливо прогнозувати розвиток епідеміологічного і епізоотичного процесів та розробляти ефективні заходи щодо зниюення рівня кишкових інфекиій.

Електромагнітне випромінювання надвисокої частоти (НВЧ) иироко застосовується у повсякденному житті та медицині і відносно недавно у ветеринарній медицині, а вплив НВЧ-хвиль на клітини і організм в цілому є предметом ретельного вивчення. Розробка оптимальних режсимів НВЧ-нагрівання трунтується на біофізичних закономірностях НВЧопромінення з клітинами і механізмі поглинання НВЧ-енергії клітинними суспензіями.

Витримування бульйонної та агарової культур сальмонел у мікрохвильовій печі впродовж 30 секунд достатнє для знищення цих мікроорганізмів.

Тож ми припускаємо, що електромагнітне випромінювання мікрохвильової печі при експозицї не менше 30 сек. можна використовувати для знищення ентеропатогенних мікроорганізмів у різних субстратах.

Ключові слова: Salmonella, S.typhi, НВЧ-хвилі, мікрохвильова піч, мобільний зв'язок, Wi-Fi, лазер.

\section{Свойства salmonella typhi при воздействии электромагнитного излучения сверхвысокой частоты}

\author{
О.В. Яблонская, Н.Я. Мех, Т.А. Духнич \\ yablonska.oksana@gmail.com
}

Национальный университет биоресурсов и природопользования Украины,

ул. Героев Обороны, 11, Киев, 03041, Украина

\begin{abstract}
В Украине роль сальмонелл в этиологии кишечных заболеваний людей и животных остается важной, поскольку наблюдаются изменения в серовариантной структуре этих патогенов, которые умело адаптируются к условиям внешней среды. Без изучения биологических свойств возбудителей, их учета невозможно прогнозировать развитие эпидемиологического и эпизоотического прочессов и разрабатывать эффективные мероприятия относительно снижения уровня кишечных инфекциий.

Электромагнитное излучение сверхвысокой частоты (СВЧ) широко применяется в повседневной жсизни и медицине и относительно недавно в ветеринарной медииине, а влияние СВЧ-волн на клетки и организм в целом является предметом тщңательного изучения. Разработка оптимальных режимов СВЧ-нагревания базируется на биофизических закономерностях СВЧ-облучения с клетками и механизме поглощения СВЧ-энергии клеточными суспензиями.

Выдерживание бульонной и агаровой культур сальмонелл в микроволновой печи уничтожает их через 30 секунд. Поэтому мы считаем, что электромагнитное излучение микроволновой печи при экспозиции не менее 30 сек. можна использовать для уничтожения энтеропатогенных микроорганизмов в разных субстратах.
\end{abstract}

Ключевые слова: Salmonella, S.typhi, НВЧ-волны, микроволновая печь, мобильная связь, Wi-Fi, лазер.

Citation:

Yablonska, O.V., Mekh, N.Y., Duhnich, T.A. (2016). Properties with salmonella typhi electromagnetic radiation of ultrahigh frequency. Scientific Messenger LNUVMBT named after S.Z. Gzhytskyj, 18, 3(71), 205-208. 


\title{
Properties with salmonella typhi electromagnetic radiation of ultrahigh frequency
}

\author{
O.V. Yablonska, N.Y. Mekh, T.A .Duhnich \\ yablonska.oksana@gmail.com \\ National University of life and environmental sciences of Ukraine, \\ Heroyiv Oborony Str., 11, Kyiv, 03041, Ukraine
}

\begin{abstract}
In Ukraine, a role in the etiology of Salmonella enteric disease in humans and animals is important because there are changes in the structure of these pathogens serovariantic who skillfully adapted to the environmental conditions. Without studying the biological properties of pathogens, their accounting is impossible to predict the development of epidemiological and epizootic processes and to develop effective measures regarding the reduction of intestinal infections.

Electromagnetic radiation of ultra-high frequency $(U H F)$ is widely used in everyday life and medicine and more recently in veterinary medicine, and the effect of microwaves on the cells and the organism as a whole is the subject of scrutiny. Development of optimal microwave heating modes based on biophysical laws of microwave radiation with cells and the mechanism of absorption of microwave energy cell suspensions.

Curing agar and broth cultures of Salmonella in the microwave destroys them after 30 seconds.

Therefore, we believe that the electromagnetic radiation of the microwave oven when it is exposed for at least 30 seconds. It can be used for the destruction of enteropathogenic microorganisms in different substrates.

Keywords: Salmonella, S.typhi, MPN-waves, microwaves, mobile phones, Wi-Fi, a laser.
\end{abstract}

\section{Вступ}

В Україні роль сальмонел в етіології кишкових захворювань людей і тварин залишається важливою, оскільки спостерігаються зміни у сероваріантній структурі цих патогенів, які уміло адаптуються до умов довкілля (Drahut, 2006).

Електромагнітне випромінювання (EMB) надвисокої частоти (НВЧ) широко застосовується у повсякденному житті та медицині і відносно недавно у ветеринарній медицині. А вплив НВЧ-хвиль на клітини і організм в цілому є предметом ретельного вивчення. Розробка оптимальних режимів НВЧ-нагрівання грунтується на біофізичних закономірностях НВЧопромінення 3 клітинами i механізмі поглинання НВЧ-енергії клітинними суспензіями (Ihnatov et al., 1978).

\section{Матеріал і методи досліджень}

Робота виконувалась протягом 2015 - 2016 років на кафедрі мікробіології, вірусології та біотехнології НУБІП України та у відділі біотехнології і контролю бактеріальних препаратів Державного науковоконтрольного інституту біотехнології і штамів мікроорганізмів.

Матеріали дослідження: мікрохвильова піч (МХП) марки Digital DM-SG2593W, частота коливань - 2450 МГц; мобільні телефони марок Samsung в різних режимах використання (дзвінок частота коливань - 1,5 ГГц, режим Wi-Fi в активному стані - 2,4 ГГц); лазерна указка, яка генерує когерентне та монохроматичне ЕМВ червоного кольору, потужністю 1-20 мВт.

У якості тест-мікроорганізма використовували чисту культуру Salmonella enterica subspecies enterica serovar Typhi, отриману з відділу біотехнології і контролю бактеріальних препаратів ДНКІБШМ.
Досліджувану культуру сальмонел висівали на 9 пробірок скошеного м'ясо-пептонного агару (МПА) i 9 пробірок м'ясо-пептонного бульйону (МПБ) і піддавали дії ЕMB, яке генерують дані прилади. Час досліджуваної експозиції складав 30 та 5 секунд.

Сальмонели у пробірках №1 та №2 витримували у МХП в режимі «авторозігрів» при частоті коливань 2450 МГц — №1 впродовж 30 сек., №2 - впродовж 5 сек.; пробірки №3 та №4 ставили між двома мобільними телефонами та проводили дзвінок $з$ одного пристрою на інший, частота коливань хвилі 1,5 ГГц №3 впродовж 30 сек., №4 - впродовж 5 сек.; сальмонели у пробірках №5 та №6 піддавали дії ЕMB, яке випромінюється телефоном при активній роботі $\mathrm{Wi}-$ $\mathrm{Fi}$, частота коливань - 2,4 ГГц - №5 впродовж 30 сек., №6 - впродовж 5 сек.; сальмонели у пробірках №7 та №8 піддавали дії ЕMB, яке генерує лазерна указка потужністю 10 мВт — №7 впродовж 30 сек., №8 - впродовж 5 сек.; сальмонели у пробірках №9 були інтактними, тобто не піддавалися дії ЕМВ.

Після опромінення усі пробірки інкубували у термостаті $24 \pm 2$ години при температурі $37 \pm 1^{\circ} \mathrm{C}$ п подальшим аналізом росту сальмонел, готуванням мазків, фарбуванням за методом Грама і мікроскопією при імерсії.

\section{Результати та їх обговорення}

За даними вчених (Levina, 1977) сальмонели у МПБ спричинюють інтенсивне помутніння, утворюючи великий осад на дні пробірки та плівку на поверхні. Ми ж після 24-годинного інкубування досліджуваних сальмонел проби №1 виявили прозорий бульйон без осаду (рис. 1) та абсолютно каламутний МПБ у пробірках № 2-9 (рис. 2). 


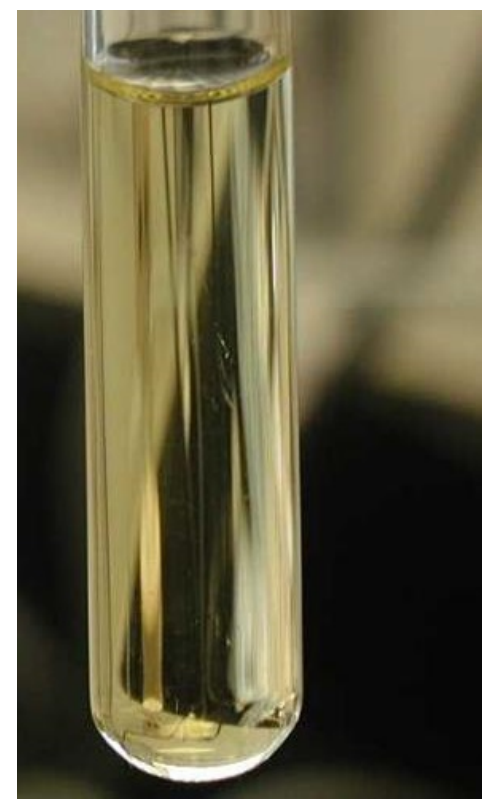

Рис. 1
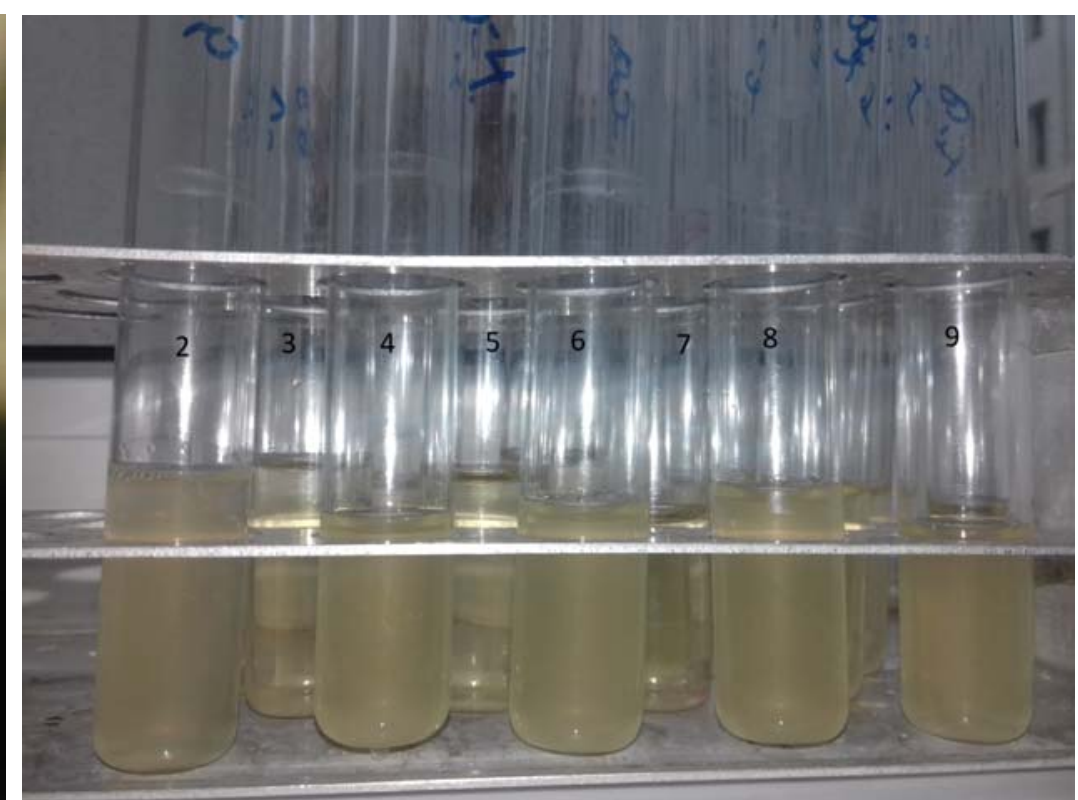

Рис. 2

Ріст досліджуваних сальмонел на МПБ після дії НВЧ-хвиль

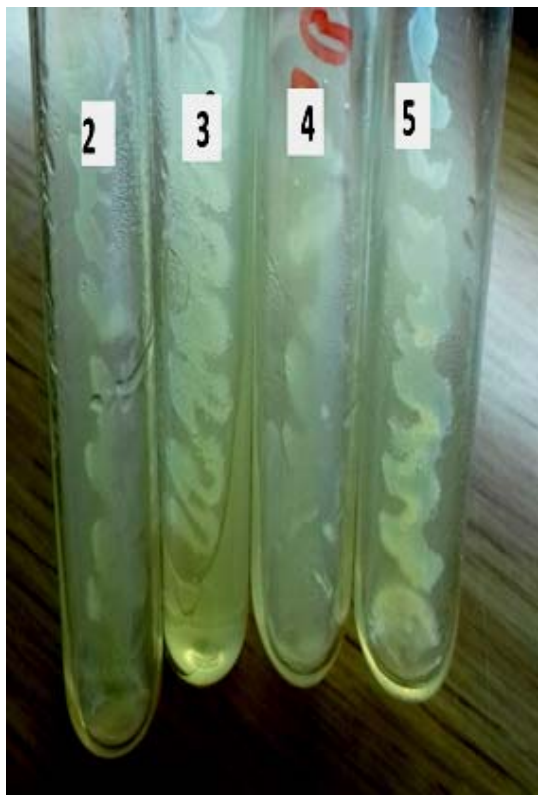

Рис. 3

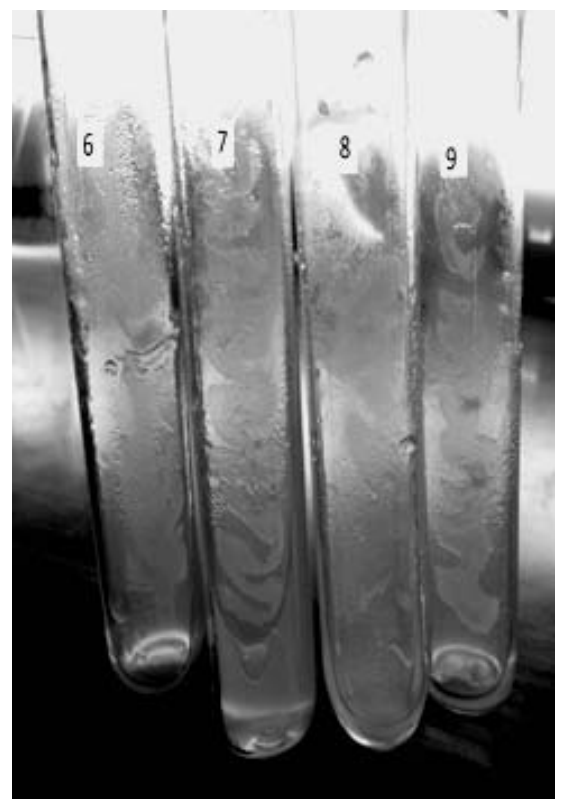

Рис. 4

Ріст досліджуваних сальмонел на МПБ після дії НВЧ-хвиль

Після посіву на МПА впродовж 24 год сальмонели утворюють округлі колонії діаметром 2-5 мкм, що мають сірувато-білий колір з блакитним відтінком та соковиту, блискучу поверхню [4]. Після інкубування сальмонел ми виявили у пробірці №1 чистий МПА без ознак росту мікроорганізмів на фоні росту характерних колоній у пробірках №2-№9 (рис. 3 і 4).

Морфологічно S.typhi не відрізняються між собою і мають вигляд грамнегативних (Гр-), рухливих паличок 3 округлими кінцями, величиною (1..4) $\times$ $(0,4 \ldots 0,8)$ мкм. Добре забарвлюються усіма аніліновими фарбами. Спор і капсул не утворюють. Ростуть на звичайних живильних середовищах в аеробних i анаеробних умовах при $\mathrm{pH}=7,2-7,6$, за температури $36-38^{\circ} \mathrm{C}$.

При мікроскопії мазків, виготовлених з МПБ та МПА, які були у пробірках №1, нами не було виявлено мікроорганізмів.

У мазках 3 пробірок №2 бульйонної та агарової культур палички виявилися довшими, товстішими та збільшеними в об’ємі (рис. 5-а), з пробірок №3 - маленькі кокоподібні скупчені мікроорганізми, деякі з'єднані у ланцюжок (рис. 5-б), пробірок №4 - скупчення довгих тоненьких паличок (рис. 5-в), №5 довгі палички, темно-фіолетові, які модифікувалися у грампозитивні (рис. 5-г). 

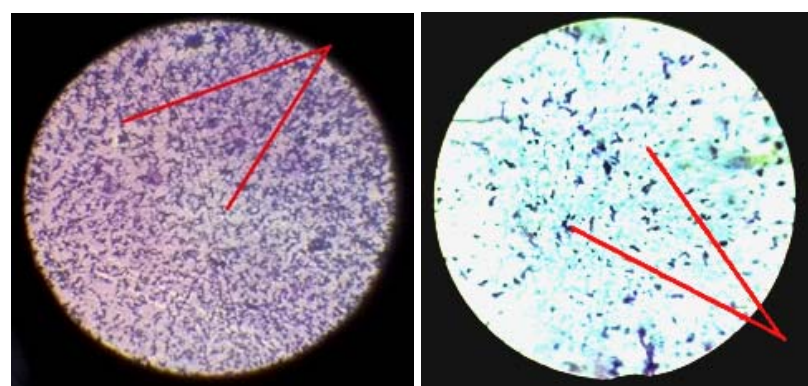

Рис. 5. Мікроскопія мазків, виготовлених з МПБ та МПА
У мазках з пробірок №6 спостерігали темно-фіолетові палички, формування захисної плівки на МПБ (рис. 6-a), з пробірок №7 - кокоподібні, дрібні, Гр- палич-

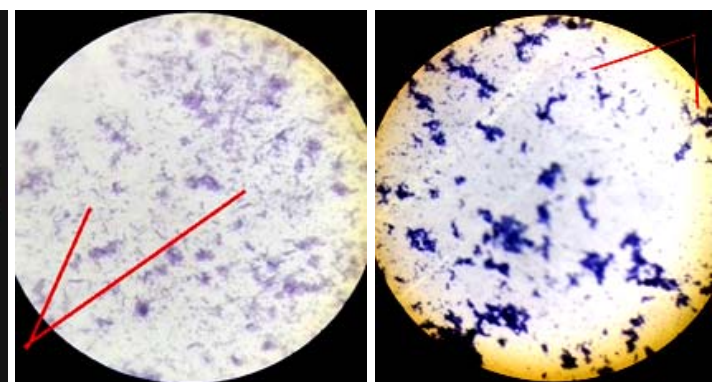

$\Gamma$

ки (рис. 6-б), пробірок №8 - №8 короткі, дрібні палички із заокругленими кінцями (рис. 6-в), №9-Гртовсті палички (рис. 6-г).

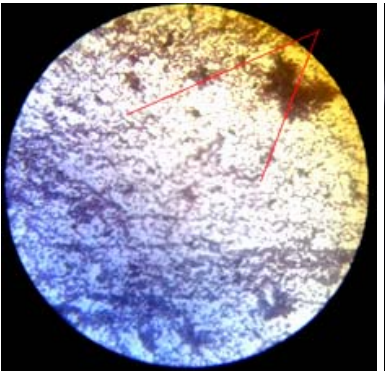

a

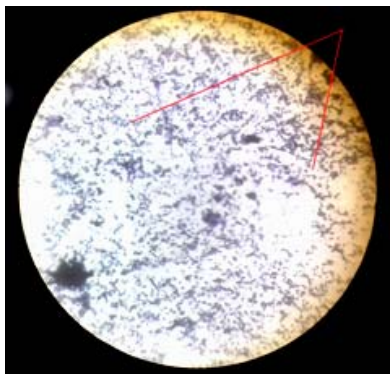

б

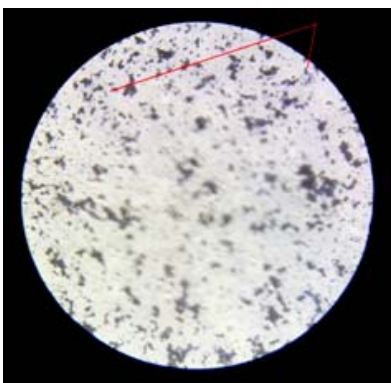

B
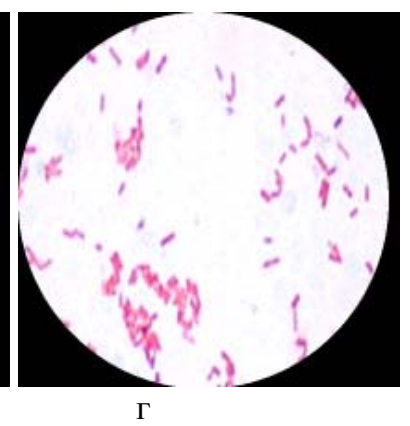

Рис. 6. Мікроскопія мазків, виготовлених з МПБ та МПА

\section{Висновки}

При вивченні дії електромагнітних випромінювань на мікроорганізми S.typhi нами було встановлено наступне:

Електромагнітні випромінювання мають значний вплив на сальмонели, залежно від тривалості впливу та частоти коливання хвиль проявляються різні зміни. При короткочасній експозиції можуть спонукати ріст та модифікацію паличок, при довготривалій - знищувати їх.

Найзначніший вплив на S.typhi мають EMB мікрохвильової печі з частотою коливання 2450 мГц, при дії на них 30 сек. і більше в режимах «розігрів» та «авто». Дії 10 сек. не вистачає для повного знешкодження даних бактерій, але їх кількість значно знижується, а часу 5 сек. не достатньо для знешкодження.

Дія ЕМВ при телефонному дзвінку протягом 30 сек. та частотою коливань 1,5 ГГц на S.typhi деформує клітинну стінку, змінює форму сальмонел та розмір. При експозиції 5 сек. - мікроорганізми видовжуються.

При активному режимі роботи $\mathrm{Wi}-\mathrm{Fi}$ протягом 30 та 5 сек. 3 частотою коливань - 2,4 ГГц S.typhi з грамнегативної модифікувалися у грампозитивні палички, дане явище відбулося через зменшення рідини в цитоплазмі і збільшення кількості пептидоглікану, який впливає на можливість фарбуватися аніліновими барвниками.

Отже, електромагнітне випромінювання мікрохвильової печі при експозиції не менше 30 сек. можна використовувати для знищення ентеропатогенних мікроорганізмів у різних субстратах.

Перспективи подальших досліджень - розробка енергозберігаючих технологій знешкодження, стерилізації або пастеризації за допомогою НВЧ-енергії м'яса, м'ясопродуктів, м'ясних боєнських відходів, рибопродуктів.

\section{Бібліографічні посилання}

Drahut, S.S. (2006). Biologichni vlastyvosti zbudnyka, udoskonalennia diagnostyky ta likuval'noprofilaktychnykh zasobiv pry salmonelozi ptytsi: avtoref. dys.... cand. vet. nauk: 16.00.03. Kh., 21 (in Ukrainian).

Ihnatov, V.V., Panasenko, A.P., Radin, Iu.P., Shenderov B.A. (1978). Vlijanije elektromagnitnykh poliej sverkhvysokochastotnogo diapazona na bakterialnuju kletku. Saratov (in Russian).

Levina, V.P.(1977). Immunoluminestsentsia v meditsine. M.: Meditsina (in Russian).

Стаття надійшла до редакиії 5.09.2016 